\title{
Financial Contagion in EFA Markets in Crisis Periods: A Multivariate GARCH Dynamic Conditional Correlation Framework
}

\section{Mobeen Ur Rehman*}

\begin{abstract}
This paper uses the multivariate GARCH dynamic conditional correlation framework proposed by Engle (2002) to investigate time-varying conditional correlation between developed markets and emerging and frontier Asian (EFA) markets. It employs monthly returns data for 2000-14 to capture the potential contagion in developed (the US, Europe and Japan) and EFA stock markets. A key finding is the increasing conditional correlation among EFA and developed markets, especially during the 2008 financial crisis. The study finds that, during periods of financial turmoil, EFA markets are exposed to shocks and spillover effects from developed markets along with a substantial shift in the regime of conditional correlation. This has important implications for investors interested in diversifying portfolios in EFA markets during financial crises.
\end{abstract}

Keywords: Emerging and frontier Asian markets, financial contagion, financial crisis, dynamic conditional correlation.

JEL classification: G11, G15, F3, F65.

\section{Introduction}

A number of emerging market economies experienced crises in the 1990s, including the 'Tequila effect' of 1994, the Asian financial crisis of 1997, the Russian 'cold' of 1998 and Brazil 'fever' of 1999. While these started as country-specific events, the effects soon spread to other countries and had a worldwide impact. Indeed, the past decade has seen a great deal of news centering on financial crises and economic depressions. The term 'financial crisis' encompasses several subsets of crises, such as in banking, exchange rates and stock markets. The transmission of a financial crisis from its

\footnotetext{
* Assistant Professor, Shaheed Zulfikar Ali Bhutto Institute of Science and Technology, Islamabad, Pakistan.
} 
country of origin (as a country-specific phenomenon) to other countries occurs through the contagion effect. ${ }^{1}$

The literature describes three categories of financial crises. The firstgeneration concept proposed by Flood and Garber (1984) and by Krugman (1997) looks at the existence of speculative shocks and their impact on exchange reserves. These studies suggest that such crises occur when macroeconomic fundamentals are neglected. Obstfeld and Rogoff (1994) and Cole and Kehoe (1996) attribute second-generation crises to the financial turbulence that hit the European monetary system in 1992/93 (considered the first financial globalization experience). Obstfeld and Rogoff (1994) argue that this particular crisis resulted from the conflict between fixed exchange rate regimes and government attempts to implement a more expansionist monetary policy.

The third-generation concept has emerged from the Asian crisis. The model proposed by Krugman (2001) and Cartapanis and Gilles (2003) is an accumulation of the first- and second-generation crises, combining the twin crises in exchange rates and banking. This also reveals the fragility of the financial and banking spheres. Such crises tend to occur when banking sector panic moves the economy from a good equilibrium to a crisis equilibrium. This is what most researchers refer to as the contagion effect ${ }^{2}$ although there is little consensus on its precise definition and origin.

Definitions of financial contagion vary widely in the literature on financial crises. ${ }^{3}$ The definition most commonly used is that of Eichengreen and Hausmann (1999), who describe contagion as a significant increase in the crisis probability of a country, conditioned by the occurrence of a crisis in another country. This definition is important in models where exchange rate collapse is the main cause of a financial crisis. In practice, this requires a sufficiently large number of countries that are experiencing a crisis.

Market volatility is another aspect of contagion, referring to cases where volatility in one financial market spills over into another in a crisis period. In empirical terms, an analysis of equity market co-movements reveals that financial turmoil triggers stock market volatility. This suggests

\footnotetext{
${ }^{1}$ Contagion is also defined as increased correlation values among countries' asset returns in different financial markets.

2 According to Forbes and Rigobon (2002), contagion refers to an increase in cross-market comovement among stock returns in a crisis period. Any interdependence before and after the crisis is referred to as interdependence between the associated markets, whereas contagion is an increase in such linkages during the financial turmoil.

${ }^{3}$ See Masson (1999) and Pericoli and Sbracia (2003) for different definitions of financial contagion.
} 
that an increase in volatility can help identify a crisis. The contagion effect is the speed at which this volatility is transmitted. There is much debate on the medium through which this effect occurs: the herding effect and irrational investor behavior are often cited as likely channels.

Forbes and Rigobon (2001) show that contagion is the result of a significant increase in financial market linkages lagged by a shock in a country or group of countries. This increase in financial linkages among various markets has implications for how transmission channels are generated and how they intensify in a crisis period for a given country, irrespective of its fundamentals. In general, contagion is the expansion of one country's financial market disturbances to another country or group of countries. This expansion is evident from the increasing level of comovement among exchange rates, capital mobility and spreads in liability.

In this study, we adopt the definition proposed by Forbes and Rigobon (2002). Instead of explaining the mechanism through which shocks are propagated at the international level, we define contagion as an increase in cross-market linkages resulting from the shocks to a country or group of countries. Therefore, in the case of higher-return co-movement before and during a crisis, we use the term 'cross-market interdependence' rather than 'the contagion effect' as the latter is associated with an increase in the relationship only in a crisis period (Caporale, Cipollini \& Spagnolo, 2005). Studying crises and their aftermath helps researchers investigate the initiation and transmission of such shocks to various markets across the world. ${ }^{4}$

The rest of the paper is structured as follows. Section 2 reviews the literature on contagion models. Section 3 explains the econometric techniques used and Section 4 interprets the data.

\section{Literature Review}

Carrieri, Errunza and Hogan (2007) show that integration among world stock markets tends to increase over time. In recent years, there has been a significant increase in private capital inflows from developed to emerging markets. With growing integration between developing and

\footnotetext{
${ }^{4}$ Pritsker (2001) outlines four different transmission channels: correlated information (King \& Wadhwani, 1990) or the wakeup-call hypothesis (Sachs, Tornell \& Velasco, 1996), the wealth effect (Kyle \& Xiong, 2001), liquidity (Claessens, Dornbush \& Park, 2001) and cross-market hedging (Kodres \& Pritsker, 2002). Although using specific transmission channels to test for financial contagion may be more useful, insufficient microstructure data makes this more difficult without any priori identification of the relevant fundamental variables. As a result, many empirical studies apply different correlation methods to investigate the co-movement of asset returns in an effort to analyze the contagion effect.
} 
emerging markets and the world market, financial crises have gained more importance. While Broner, Gelos and Reinhart (2006) argue that contagion results from scaling back overweighed areas, Bayoumi et al. (2007) show that an important precondition of a financial crisis may be the herding behavior of developed market ${ }^{5}$ investors in emerging markets. Collins and Gavron (2004) identify seven major financial crises in the following order: the Czech koruna crisis (May 1997), the Asian crisis (July 1997), the Zimbabwean dollar crisis (November 1998), the default crisis in Russia (August 1998), the Brazilian real crisis (January 1999), the Argentine peso crisis (July 2001), the dot.com bubble crisis (March 2000), the world stock market crash (September 2008) and the European debt crisis (January 2011). ${ }^{6}$

Bensafta and Semedo (2014) analyze different financial markets using multivariate return dynamics. They model the conditional mean of returns using vector autoregression and the conditional variance using a multivariate GARCH framework.7 Wongswan (2006) applies a stock volatility model to high-frequency data for US, Korean, Japanese and Thai stock market returns. The author studies the effect of macroeconomic announcements in the US and Japan on trading volume and stock volatility in Thailand and Korea. Edwards and Susmel (2003) use a switching ARCH model to examine interest rate volatility in emerging markets and identify periods of high volatility. They conclude that volatility transmission patterns are geographically distinct.

Looking at shocks spread across the asset markets of eight Latin American economies, Martinez and Ramirez (2011) measure market reactions using principal component analysis and an $\mathrm{ARCH} / \mathrm{GARCH}$ framework to investigate asset market volatility. While their study does not support the hypothesis of financial contagion, the interrelationship among various markets is evident, as is their mild sensitivity to recent shocks. However, the study is limited in that it does not include emerging and frontier Asian (EFA) markets.

\footnotetext{
${ }^{5}$ Fong (2003) observes a smaller degree of correlation for Canada, with significant results by pairing the US with four major markets. The author applies a bivariate regime-switching model with the same limitation of assuming a single country (the US in this case) as the source of propagating volatility shocks.

${ }^{6}$ In another instance, the Hong Kong market is assumed to be the origin of contagion. This treatment does not yield sound results: in a crisis period, adverse situations can trigger turbulence in any neighboring financial market. This leads to the bias of simultaneous equations.

${ }^{7}$ This involves a similar multivariate GARCH model, along with constant conditional correlation to estimate the correlation coefficients, using breakpoints to split a single sample period into two. The results are similar to those achieved under unconditional correlation.
} 
Unlike most other studies, we examine EFA markets against a panel of developed markets - the US, Japan and Europe. Contrary to Martinez and Ramirez (2011), $\mathrm{Li}$ (2007) investigates the existence of a volatility relationship between two emerging (Hong Kong and China) markets and a developed market (the US), using a multivariate GARCH model. ${ }^{8} \mathrm{Li}$ yields better results as the application of multivariate GARCH dynamic conditional correlation (DCC) models allows the flexibility of univariate GARCH techniques along with parsimonious parametric models to measure correlation.

The proposed multivariate GARCH model resembles the BEKK framework (Engle \& Kroner, 1995) used to capture the regularities characterizing stock market indices. Our study can therefore be considered an extension of $\mathrm{Li}$ (2007) in that it incorporates the effects of the 2008/09 global financial crisis with a larger panel of both developed and emerging markets. $\mathrm{Yu}$, Fung and Tam (2010) also use a DCC-GARCH model to analyze crossmarket correlation among 11 markets. ${ }^{9}$ Unlike traditional GARCH models, their results show a strong contagion effect from the US economy to the Asian economies during the 2007 crisis, whereas there is no spillover from the Asian markets to the developed markets during the Asian crisis period

Another important aspect of contagion is the use of conditional correlation to test the shift in linkages across financial markets during a crisis. However, a regime-switching methodology such as the Markov model provides more consistent results. Many subsequent studies have followed King and Wadhwani (1990) and attempted to refine the approach to data generation, which can have a significant effect on validity tests such as heteroskedasticity, common factor influence and endogeneity (Corsetti, Pericoli \& Sbracia, 2005).

Dungey et al. (2002) estimate a dynamic latent factor model to determine the presence of contagion in stock and bond markets during a crisis period. From a factor model perspective, Bekaert, Harvey and Lundblad (2005) find that, allowing for time-varying integration among global markets, contagion implies excess cross-country correlation in terms of model residuals in a crisis period. Given the widespread effects of past financial turmoil on frontier and emerging markets, most research has focused on contagion and financial shocks originating in these markets rather than in developed economies.

\footnotetext{
${ }^{8}$ See Longin and Solnik (1995) on the application of GARCH. The factors affecting conditional correlation can also be determined through this framework, with the limitation that one is dealing with a single factor at a time and a greater number of parameters.

${ }_{9}^{9}$ Australia, Hong Kong, Japan, Malaysia, the Philippines, Thailand, China, Indonesia, Korea, New Zealand and Singapore.
} 
Many studies have looked at the implications of market integration and liberalization for volatility spillover and the correlation of returns. However, in analyzing the linkages between mature and emerging markets, the 'shift contagion' perspective is often ignored, the volatility in mature markets having already peaked. The financial crisis of 2007/08 - and the last decade in general - have had important implications for the episodic turbulence that spills over from mature to emerging markets in the shape of the contagion effect. The Global Competitiveness Report for 2013 notes that financial crises have had a considerable impact on emerging markets. Furthermore, the tenuous recovery of the European and US markets postcrisis follows the continuous underperformance of emerging markets in terms of slower economic growth relative to previous years.

Cross-market correlation analysis is essential for risk management and optimizing cross-country portfolios. Many studies have analyzed the time-varying correlation of cross-market returns during an economic downturn caused by the transmission of shocks from other countries (Ham, Kim \& Boyce, 2005). Syllignakis and Kouretas (2011) note that many researchers define contagion as the spread of financial shocks from one country to the other. The bulk of the literature, however, focuses on various contagion channels in the context of mature markets rather than emerging and frontier markets. As a result, more research is now being conducted on cross-market time-varying correlation among emerging markets in periods of financial turmoil (Suardi, 2012).

Dooley and Hutchison's (2009) study on emerging markets during the US subprime crisis looks at market decoupling before and recoupling during the crisis period. Aloui, Aïssa and Nguyen (2011) use the copula approach to examine the returns of BRIC countries vis-à-vis the US market from 2004 to 2009. Their results indicate a high level of significant timevarying persistent correlation among these markets. Samarakoon (2011) notes that the transmission of financial shocks from the US to frontier and emerging markets reflects a strong degree of interdependence and contagion. ${ }^{10}$ However, when Choe et al. (2012) apply a structural DCC framework to a larger sample of countries during the Asian crisis of 1997, they find no evidence of contagion based on constant cross-correlation.

\footnotetext{
${ }^{10}$ Comprehensive surveys are provided by Pericoli and Sbracia (2003) and by Karolyi (2003). Masson (1998), Kaminsky and Reinhart (2000), Claessens et al. (2001) and Kaminsky, Reinhart and Vegh (2003) look at channels of financial transmission and analyze different approaches to contagion. Pritsker (2001) and Pericoli and Sbracia (2003) also examine different channels of financial contagion.
} 
In their analysis of the BRIC economies during 1995-2006, Kenourgios, Samitas and Paltalidis (2011) assess the contagion effect of financial crises on other countries for each crisis period. Further evidence of contagion emerges in Kenourgios and Padhi (2012), who find that the Russian and Asian crises had a distinct effect on emerging markets while the Argentine crisis had a limited contagion effect.

The impact of the US subprime crisis on emerging markets is analyzed by Chua, Suardi and Tsiaplias (2012), using four market indices: Latin American emerging markets, Asian emerging markets, emerging markets and the world market. Their results show that the crisis had a substantial impact on emerging and mature markets. While there is no real consensus on spillover and contagion effects from developed to emerging markets, some studies do identify such spillovers in crisis periods for selected markets. Our sample is based on the Morgan Stanley classification index in order to generalize the findings across EFA markets.

\section{Empirical Framework}

Much of the literature uses conventional time-series models such as co-integration, vector autoregression and causality tests. The volatility model is rarely used in the context of financial contagion. We employ a multivariate DCC-GARCH model to assess time-varying correlation among multiple markets. This has the advantage of ensuring the flexibility of univariate GARCH techniques along with parsimonious parametric models to measure correlation. Moreover, the model is consistent with univariate and multivariate volatility forecasts. When a new variable is added, the correlation and volatility forecasts of the original assets remain unchanged. Engle (2002) states that the DCC-GARCH models are superior to the traditional simple GARCH models in terms of the mean absolute error, tests based on value at risk and other diagnostics.

This study contributes to the literature by applying the DCCGARCH technique ${ }^{11}$ to EFA markets vis-à-vis the developed markets of US, Europe and Japan to capture the effects and transmission of financial contagion. It also presents the policy implications of changing patterns in international stock market co-movement among developed, emerging and frontier markets during a crisis. 11 Other techniques such as the BEKK and vector error correction models can also be used as
multivariate GARCH models, but they are difficult to expand to three asset returns. 


\subsection{Preliminary Analysis}

Table 1 lists the stock markets included in the sample. The last three indices represent developed markets and the rest represent EFA markets. Table 2 gives descriptive statistics for the sample stock market returns. Pakistan has the highest monthly return (1.8 percent) while Korea and Bangladesh have the lowest (0.3 percent). Pakistan also has the highest variation, almost 8.3 percent, thus representing a higher comparative risk to other markets.

The ARCH effect is present in all the markets except Thailand. The normality hypothesis is rejected for all the stock market indices. All the indices are negatively skewed, except for Bangladesh and Sri Lanka. Thailand, Indonesia, Pakistan and Bangladesh all have a leptokurtic distribution. Pakistan also has the highest return per unit of risk (RPU) (12.69 percent) while Korea has the lowest. India, the Philippines and Bangladesh have moderate RPU values of around 10 percent. The RPU has standardized returns in terms of risk. The interpretation of these values is the same as the mean values of the respective stock market indices.

Table 1: Stock markets, by country of origin and symbol

\begin{tabular}{lll}
\hline Country & \multicolumn{1}{c}{ Stock market index } & \multicolumn{1}{c}{ Symbol } \\
\hline Pakistan & Karachi Stock Exchange 100 & KSE 100 \\
India & Bombay Stock Exchange Sensex & Sensex \\
Bangladesh & Chittagong Stock Exchange & CSCX \\
China & Shanghai Composite Index & Shanghai Cp China \\
Sri Lanka & Colombo Stock Exchange & CSE \\
Indonesia & Jakarta Composite Index & Jakarta Cmp \\
Korea & Korea Composite Stock Price Index & KOSPI \\
Malaysia & Kuala Lumpur Stock Exchange Composite Index KLSE Comp \\
Philippines & Philippine Stock Exchange Composite Index & PSE Comp \\
Thailand & SET Index Thailand & SET \\
US & Standard and Poor's 1200 Index & SP 1200 \\
Europe & Dow Jones Industrial Average & DJIA \\
Japan & Nikkei 225 Index & Nikkei \\
\hline
\end{tabular}

The results of the return correlation are presented in Table 3. The Korean stock market has the highest return correlation values with respect to Europe and Japan, while the Malaysian stock market is highly correlated with the US. It is also important to note that all three developed country stock markets are moderately correlated with one another. 


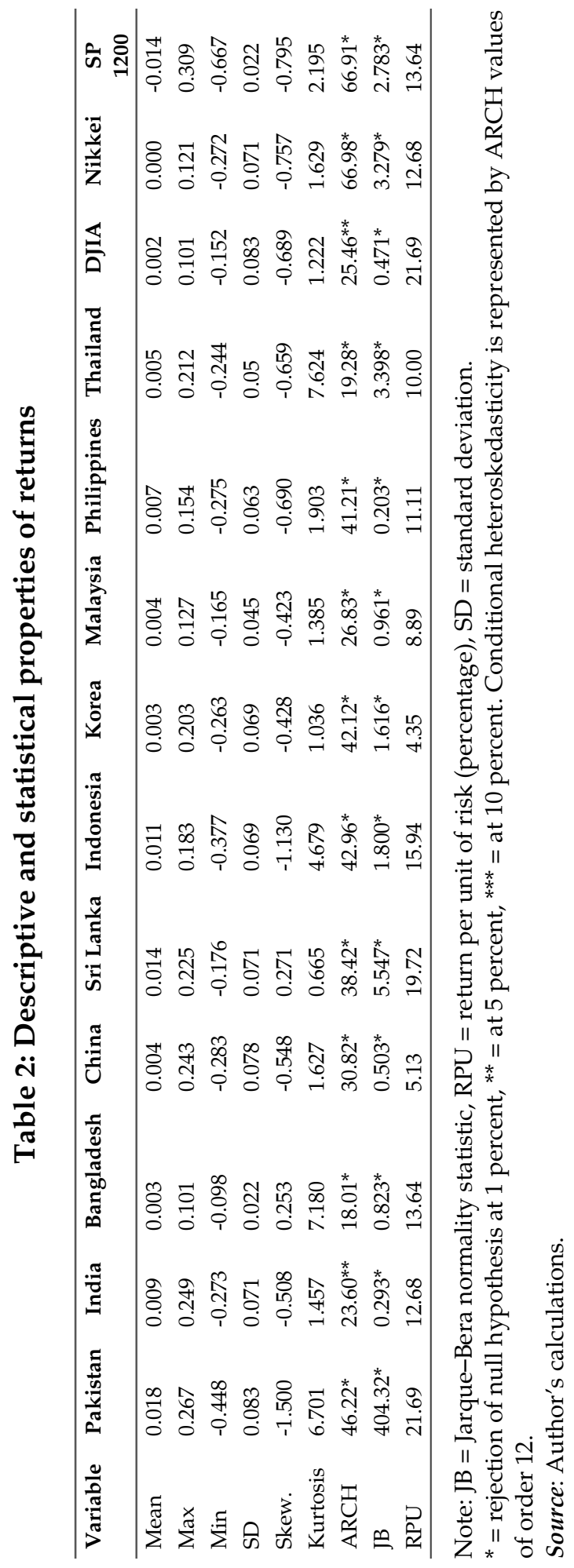




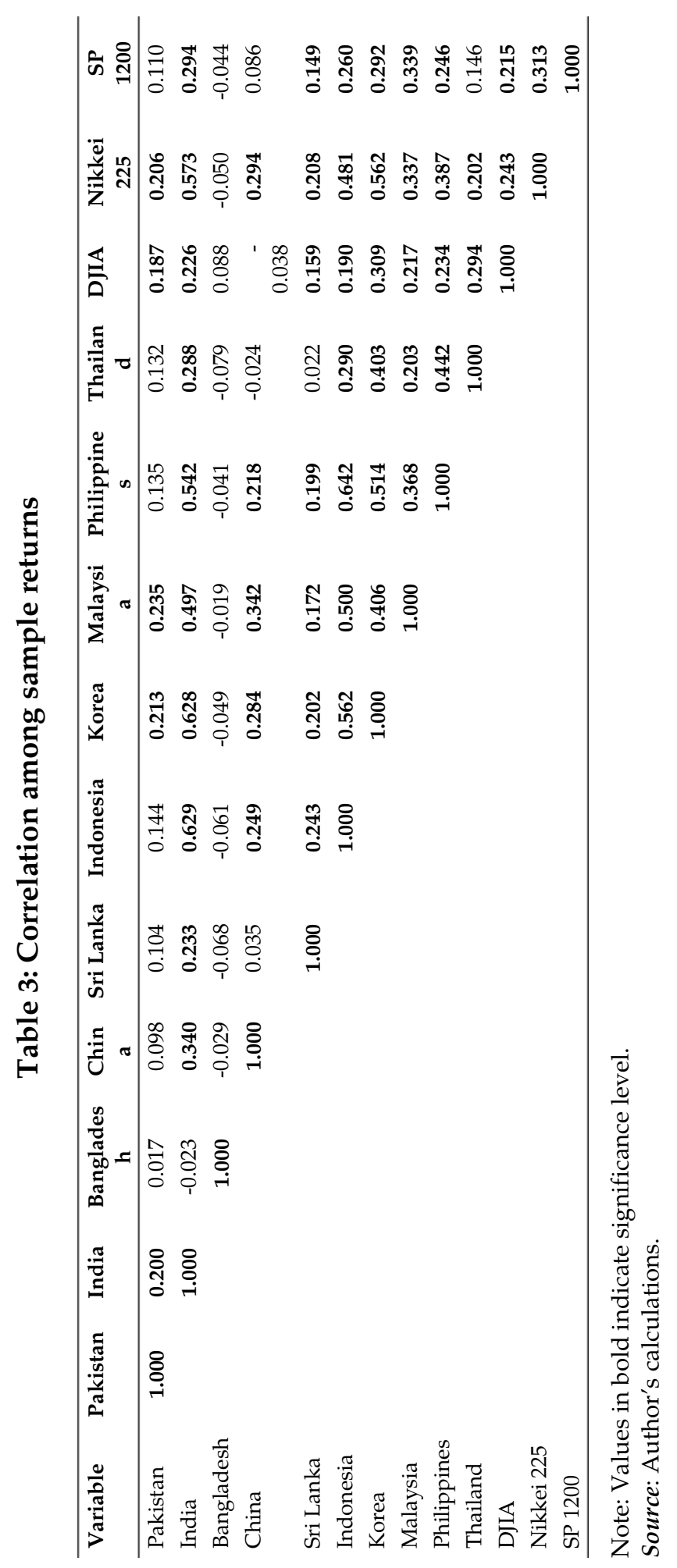


Figure 1 illustrates the average monthly returns for the sample of developed and EFA markets. It is evident that all these markets experienced disturbances in 2008/09 due to the financial crisis. Bangladesh and Thailand have the smallest comparative variation. The Chinese stock market's monthly returns exhibit the largest variation from 2006 to 2009, after which they appear to return to normal.

Figure 1: Average monthly returns for selected markets

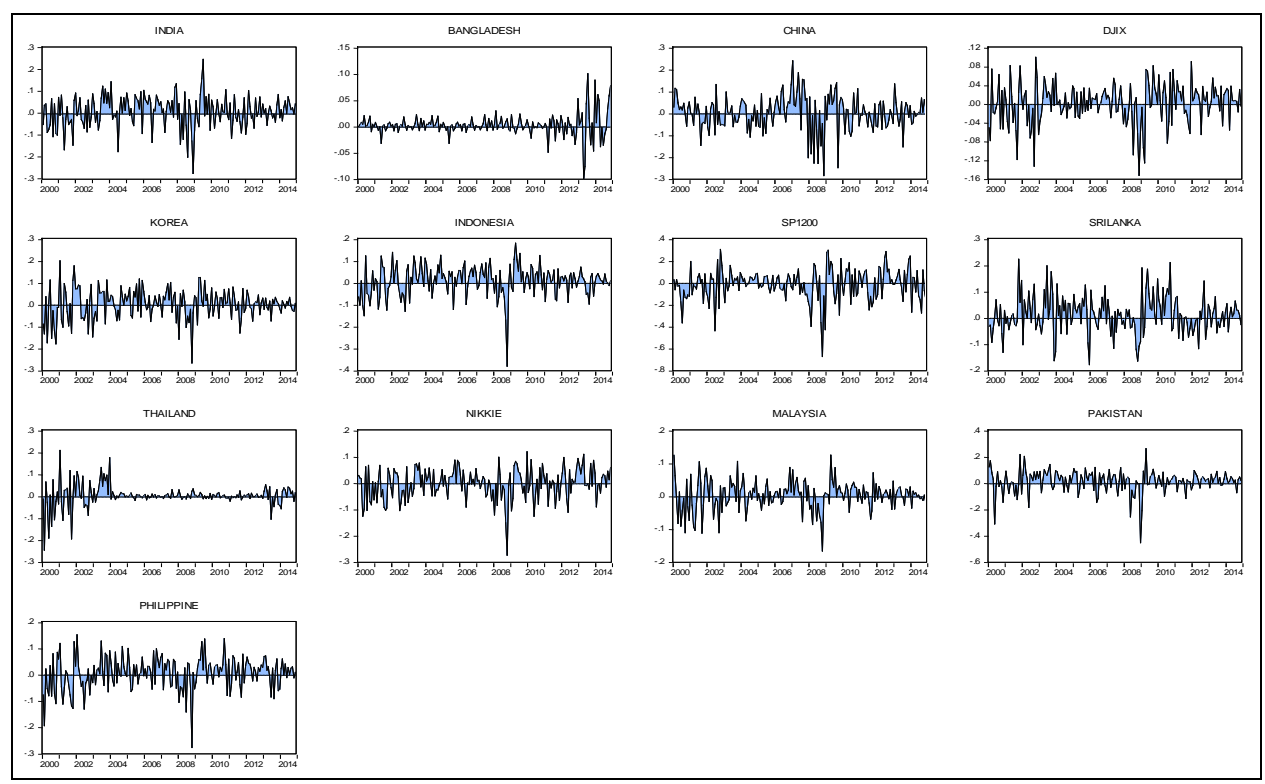

Table 4 applies the Zivot-Andrews structural break unit root test to identify the turbulence caused by the global financial crisis. The stock returns of the sample indices are all stationary at level, but the impact of the global financial crisis is obvious in most cases. Most stock markets show excessive volatility in the first quarter of 2009, while some emerging markets - China, Bangladesh and Japan (Nikkei 225) - experienced a disturbance in the second quarter of 2007. This implies that both pre-crisis and post-crisis effects were felt in the sample of developed, frontier and emerging markets. 
Table 4: Unit root test with structural break statistics

\begin{tabular}{lcl}
\hline Country or index & Zivot-Andrews stat. & \multicolumn{1}{c}{ Breakpoint date } \\
\hline Pakistan & $-9.567^{*}$ & March 2009 \\
India & $-10.623^{*}$ & March 2009 \\
Bangladesh & $-9.680^{*}$ & April 2007 \\
China & $-4.631^{*}$ & November 2007 \\
Sri Lanka & $-10.596^{*}$ & January 2009 \\
Indonesia & $-9.777^{*}$ & March 2009 \\
Korea & $-11.474^{*}$ & March 2009 \\
Malaysia & $-6.899^{*}$ & April 2009 \\
Philippines & $-11.892^{*}$ & February 2009 \\
Thailand & $-4.136^{*}$ & March 2009 \\
DJIA & $-13.076^{*}$ & April 2009 \\
Nikkei 225 & $-12.139^{*}$ & July 2007 \\
SP 1200 & $-11.458^{*}$ & June 2009 \\
\hline
\end{tabular}

Source: Author's calculations.

\subsection{Model Estimation}

The study uses Engle's (2002) model, which itself is an extension of Bollerslev, Chou and Kroner's (1992) constant conditional correlation framework. ${ }^{12}$ It was originally designed to test for a dynamic relationship between Asian and Latin American markets. A key advantage of the DCCGARCH multivariate framework is that it yields pairwise correlation coefficients in the index returns, which helps study their associated behavior during the crisis period. ${ }^{13}$ Based on Engle's assumption, the returns are calculated after filtration, as given below:

$$
\begin{aligned}
& R_{t} \mid F_{t-1} \sim N\left(0, H_{t}\right) \\
& H_{T}=D_{t} R_{t} D_{t}
\end{aligned}
$$

\footnotetext{
${ }^{12}$ Dungey et al. (2004) and Pericoli and Sbracia (2003) review various methodologies, including probability models and extreme value theory in the literature on contagion. Probability models examine crises index changes in one country due to another country, whereas extreme value theory deals with the correlation values of a returns distribution with negative values.

${ }^{13}$ Serwa and Bohl (2005) test for the contagion effect among seven developed and three emerging markets, incorporating the US stock market crash and accounting scandals of 2002. There is little evidence of contagion in Corsetti et al. (2005) and Forbes and Rigobon (2002), who use adjusting correlation coefficient variants. Studies on mature markets include Fratzscher (2002), Bae and Karolyi (1994), Longin and Solnik (1995) and Hamao, Masulis and Ng (1990). Emerging market contagion studies include Caporale, Pittis and Spagnolo (2006), Edwards (1998) and Ng (2000).
} 
In equation (2), $D_{t}$ represents a $k \times k$ diagonal matrix with a timevarying standard deviation from GARCH ${ }^{14}$ along with $\sqrt{h_{i t}}$ on the $i$ th diagonal and $R_{t}$ representing time-varying correlation. The model's log likelihood is expressed below:

$$
\begin{aligned}
L & =-\frac{1}{2} \sum_{t=1}^{T}\left(k \log (2 \pi)+2 \log \left|H_{t}\right|+r_{t} H_{t}^{-1} r_{t}\right) \\
& =-\frac{1}{2} \sum_{t=1}^{T}\left(k \log (2 \pi)+2 \log \left|D_{t} R_{t} D_{t}\right|+r_{t} D_{t}^{-1} R_{t}^{-1} D_{t}^{-1} r_{t}\right) \\
& =-\frac{1}{2} \sum_{t=1}^{T}\left(k \log (2 \pi)+2 \log \left|D_{t}\right|+\log \left(\left|R_{t}\right|+\epsilon_{t} R_{t}^{-1} \epsilon_{t}\right)\right.
\end{aligned}
$$

Here, $\epsilon_{t} \sim N(0, R)$ are the standardized residuals based on their conditional standard deviations. To obtain the individual asset conditional variance, we write the univariate GARCH model as

$$
h_{i t}=\omega_{i}+\sum_{q=1}^{p i} \propto_{i p} r_{i t-p}^{2}+\sum_{q=1}^{Q i} \beta_{i q} h_{i t-p} \text { for } i=1,2,3 \ldots k
$$

Given the normal restrictions of stationarity and nonnegativity (of variances), and with GARCH $\sum_{p=1}^{p i} \alpha_{i p}+\sum_{q=1}^{Q i} \beta_{i q}<1$, the correlation structure of the proposed dynamic is:

$$
\begin{aligned}
& Q_{t}=\left(1-\sum_{m-1}^{M} \alpha_{n}-\sum_{n-1}^{N} \beta_{n}\right) \bar{Q}+\sum_{m-1}^{M} \alpha_{m}\left(\epsilon_{t-m} \epsilon_{t-m}^{\prime}\right)+ \\
& \sum_{n=1}^{N} \beta_{n} Q_{t-n} \\
& R_{t}=Q_{t}^{*-1} Q_{t} Q_{t}^{*-1}
\end{aligned}
$$

where $\bar{Q}$ is the unconditional covariance of the standardized residuals from the univariate GARCH equation. The diagonal matrix for $Q_{t}^{\prime}$ is:

\footnotetext{
14 Mean equation: $r_{t}=\gamma_{1} r_{t-1}+\gamma_{2} r_{t-1}^{U S, E U R, J A P} \varepsilon_{t} \quad$ where $\quad r_{1}=\left(r_{1, t}, r_{2, t}, \ldots r_{10, t}\right), \varepsilon_{t}=$ $\left(\varepsilon_{1, t}, \varepsilon_{2, t}, \ldots \varepsilon_{10, t}\right)$ and $\varepsilon_{t} \mid I_{t-1} \sim N\left(0, H_{t}\right)$.

Variance equation: $h_{i i, t}=\omega_{i}+\alpha_{i, 1 \varepsilon_{i, t-1}^{2}}+\beta_{i, 1} h_{i i, t-1}$, for $i=1,2, \ldots 10$.$$
q_{i j, t}=\rho_{i j}(1-a-b)+b q_{i j, t-1}+a \aleph_{i, t-1} \aleph_{j, t-1}
$$

DCC equation: $\rho_{i j, t}=\frac{q_{i j, t}}{\sqrt{q_{i i, t} \sqrt{q_{j j, t}}}}$ where $i, j=1,2, \ldots 10$, and $i \neq j$.
} 


$$
Q_{t}^{\prime}=\left[\begin{array}{cccc}
\sqrt{q_{11}} & 0 & \cdots & 0 \\
0 & \sqrt{q_{22}} & \cdots & 0 \\
\vdots & \vdots & \vdots & 0 \\
0 & 0 & \cdots & \sqrt{q_{k k}}
\end{array}\right]
$$

The expression for $R_{t}$ is given by $\rho_{i j t}=\frac{q_{i j t}}{\sqrt{q_{i i} q_{j j}}}$. The $R_{t}$ matrix is a positive constant that can be written as $H_{t}=D_{t} R_{t} D_{t}$.

\subsection{Results of Multivariate DCC-GARCH Model}

Panels A, B and C of Table 5 present the results of the multivariate DCC-GARCH model. In panel A, the constant term in the mean equation is statistically significant for all markets except China, Korea and Thailand. In panel B, it is significant only for Pakistan, Bangladesh, Sri Lanka, Indonesia and the Philippines. In panel C, the constant is significant for all countries except China, Korea and Malaysia. The autoregressive term in the mean equation $\left(\gamma_{1}\right)$ is statistically significant for Indonesia and Thailand in panels $A$ and $C$, and insignificant for all countries except Indonesia and Thailand in panel B. The effect $\left(\gamma_{2}\right)$ of US markets on EFA stock returns is highly significant for all markets except China, India and Sri Lanka in panel A and for all markets other than India and Bangladesh in panel C. 


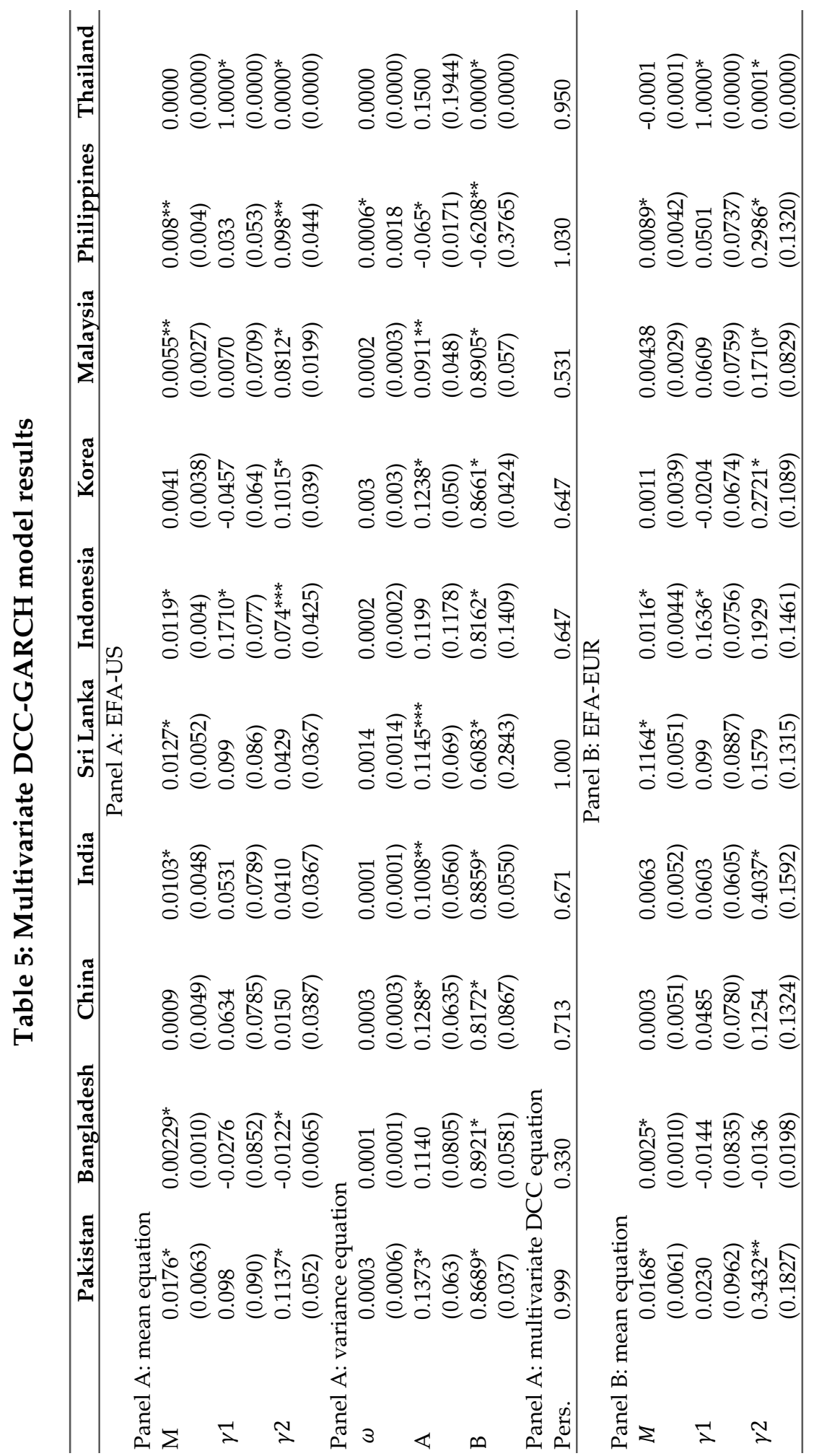




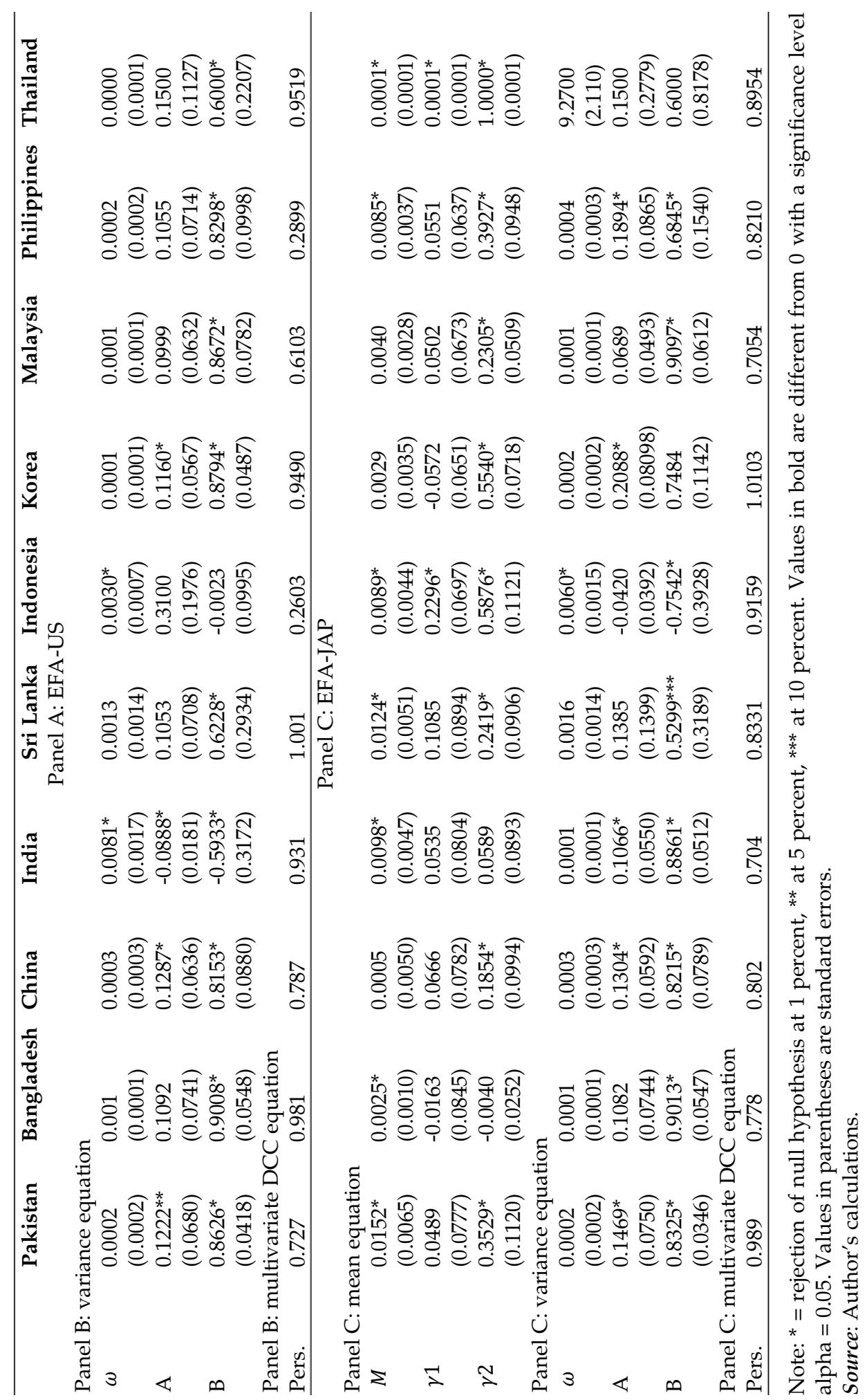


The last two rows of each panel report the estimates for DCC $(1,1)$ persistence. All the countries have high persistence values except for Bangladesh in panel A and Indonesia and the Philippines in panel B. In panel $C$, all the countries have high values, indicating high volatility persistence across the sample. Overall, the results show that EFA markets exhibit a high volatility persistence based on their GARCH estimates. The table also reports the parameter estimates of the mean and conditional variance equation for the sample. The lagged conditional volatility coefficients and $\epsilon^{2}$ in the variance equation have high significant values, thereby justifying the use of the GARCH $(1,1)$ model to capture the contagion effect among the sample markets during a crisis.

Boyer, Kumagai and Yuan (2006) suggest that contagion can arise from a fundamental base or investor portfolio rebalancing induced behavior. The former is described as interdependence by Forbes and Rigobon (2002) and the latter as herding behavior in behavioral finance. Hirshleifer and Teoh (2003) define herding behavior as the convergence of investor behaviors: investors follow other investors, thereby trading in the same direction over a specific period. Many studies, including Corsetti et al. (2005), Chiang, Jeon and Li (2007), Boyer et al. (2006) and Jeon and Moffett (2010) use DCC measures to investigate herding behavior.

Table 6 illustrates the dynamic relationship between EFA markets and the US, Japanese and European stock markets. The results indicate that the mean and variance equation coefficients significant for Pakistan and Sri Lanka, moderately significant for Korea and Thailand and the less significant for Indonesia, Malaysia and the Philippines with respect to the developed markets of the US, Japan and Europe.

The dynamic coefficients for the EFA markets are reported in the adjacent column. Indonesia and the Philippines appear to be the only markets with significant coefficient values vis-à-vis European stock markets (DJIA). All the EFA markets have significant coefficients with respect to Japanese stock returns (Nikkei), barring Korea and the Philippines. Thailand, Malaysia, Indonesia and Sri Lanka's stock markets appear to have significant values with respect to US returns (SP 1200). 
Table 6: Dynamic relationship between EFA and stock markets

\begin{tabular}{|c|c|c|c|c|}
\hline \multirow[b]{2}{*}{$\begin{array}{l}\text { Dependent } \\
\text { variables }\end{array}$} & \multicolumn{4}{|c|}{ Independent variables } \\
\hline & $\begin{array}{c}\text { DCC } \\
\text { estimation }\end{array}$ & DJIA & Nikkei & SP 1200 \\
\hline Pakistan & & $\begin{array}{c}0.2962 \\
(0.1243)\end{array}$ & $\begin{array}{l}0.4655^{*} \\
(0.094)\end{array}$ & $\begin{array}{c}0.0507 \\
(0.0356)\end{array}$ \\
\hline$\phi$ & $\begin{array}{l}0.3244^{*} \\
(0.1090)\end{array}$ & & & \\
\hline 6 & $\begin{array}{l}0.6230^{*} \\
(0.1076)\end{array}$ & & & \\
\hline$\gamma$ & $\begin{array}{l}0.0005^{* *} \\
(0.0003)\end{array}$ & & & \\
\hline Sri Lanka & & $\begin{array}{l}-0.1288 \\
(0.1335)\end{array}$ & $\begin{array}{l}0.1799 * * \\
(0.1026)\end{array}$ & $\begin{array}{l}0.0769^{*} \\
(0.0386)\end{array}$ \\
\hline$\Phi$ & $\begin{array}{l}0.1403^{* *} \\
(0.0770)\end{array}$ & & & \\
\hline 6 & $\begin{array}{l}0.6881^{*} \\
(0.1348)\end{array}$ & & & \\
\hline$\gamma$ & $\begin{array}{l}0.0009^{* *} \\
(0.0005)\end{array}$ & & & \\
\hline Indonesia & & $\begin{array}{l}0.0735^{*} \\
(0.0343)\end{array}$ & $\begin{array}{l}0.2217^{*} \\
(0.0894)\end{array}$ & $\begin{array}{l}0.0735^{*} \\
(0.0343)\end{array}$ \\
\hline$\phi$ & $\begin{array}{c}0.0990 \\
(0.0673)\end{array}$ & & & \\
\hline 6 & $\begin{array}{c}0.2360 \\
(0.5169)\end{array}$ & & & \\
\hline$\gamma$ & $\begin{array}{c}0.0032 \\
(0.0023) \\
\end{array}$ & & & \\
\hline Korea & & $\begin{array}{c}0.0327 \\
(0.0304)\end{array}$ & $\begin{array}{c}0.0575 \\
(0.1206)\end{array}$ & $\begin{array}{c}0.0327 \\
(0.0304)\end{array}$ \\
\hline$\Phi$ & $\begin{array}{c}0.0076 \\
(0.0050)\end{array}$ & & & \\
\hline 6 & $\begin{array}{l}1.0056^{*} \\
(0.0130)\end{array}$ & & & \\
\hline$\gamma$ & $\begin{array}{l}0.0001^{*} \\
(0.0001)\end{array}$ & & & \\
\hline Malaysia & & $\begin{array}{c}0.0277 \\
(0.0780)\end{array}$ & $\begin{array}{l}0.0987^{* *} \\
(0.0585)\end{array}$ & $\begin{array}{l}0.0403^{*} \\
(0.0208)\end{array}$ \\
\hline$\Phi$ & $\begin{array}{c}0.0068 \\
(0.0079)\end{array}$ & & & \\
\hline 6 & $\begin{array}{l}1.0080^{*} \\
(0.0237)\end{array}$ & & & \\
\hline$\gamma$ & $\begin{array}{l}-0.0001 \\
(0.0001)\end{array}$ & & & \\
\hline
\end{tabular}




\begin{tabular}{|c|c|c|c|c|}
\hline \multirow[b]{2}{*}{$\begin{array}{l}\text { Dependent } \\
\text { variables }\end{array}$} & \multicolumn{4}{|c|}{ Independent variables } \\
\hline & $\begin{array}{c}\text { DCC } \\
\text { estimation }\end{array}$ & DJIA & Nikkei & SP 1200 \\
\hline Philippines & & $\begin{array}{l}0.2353^{* *} \\
(0.1285)\end{array}$ & $\begin{array}{c}0.1008 \\
(0.0827)\end{array}$ & $\begin{array}{c}0.0174 \\
(0.0318)\end{array}$ \\
\hline$\Phi$ & $\begin{array}{c}0.0093 \\
(0.0499)\end{array}$ & & & \\
\hline 6 & $\begin{array}{l}0.9138^{*} \\
(0.2083)\end{array}$ & & & \\
\hline$\gamma$ & $\begin{array}{c}0.0003 \\
(0.0007)\end{array}$ & & & \\
\hline Thailand & & $\begin{array}{l}-0.0354 \\
(0.0277)\end{array}$ & $\begin{array}{c}-0.0206^{* *} \\
(0.0079)\end{array}$ & $\begin{array}{l}-0.0205^{* *} \\
(0.0079)\end{array}$ \\
\hline$\Phi$ & $\begin{array}{l}0.3566^{*} \\
(0.1099)\end{array}$ & & & \\
\hline 6 & $\begin{array}{l}0.6626^{*} \\
(0.0665)\end{array}$ & & & \\
\hline$\gamma$ & $\begin{array}{l}0.0001^{*} \\
(0.0001)\end{array}$ & & & \\
\hline
\end{tabular}

Note: $\Phi=$ mean, $\sigma=$ variance, $\gamma=$ DCC equation coefficients. ${ }^{*}=$ rejection of null hypothesis at 1 percent, ${ }^{* *}$ at 5 percent, ${ }^{* * *}$ at 10 percent. Values in bold are different from 0 with a significance level alpha $=0.05$. Values in parentheses are standard errors.

Source: Author's calculations.

\subsection{Robustness Test Results}

Tables 7 and 8 test the robustness of the DCC multivariate GARCH models. Table 7 highlights the conditional quasi-correlation among the standardized residuals of the EFA and developed markets (US, Europe and Japan) included. In almost all the markets, the conditional dynamic correlation value is lower than the unconditional correlation value presented in Table 3.

This finding has important implications for the spillover from developed to emerging markets in a period of financial turmoil. The last row presents the adjustment coefficient estimates of the DCC $(1,1)$ parameters $a$ and $b$. Both coefficients are highly significant, indicating substantial timevarying co-movement among the stock market indices of EFA and developed markets. 
Table 7: Robustness test results

\begin{tabular}{lccccccc}
\hline Variable & Pakistan & $\begin{array}{c}\text { Sri } \\
\text { Lanka }\end{array}$ & Indonesia & Korea & Malaysia & Philippines & Thailand \\
\hline Correlations & & & & & & & \\
Pakistan & $\mathbf{1 . 0 0 0}$ & 0.018 & 0.126 & 0.148 & 0.413 & -0.005 & -0.259 \\
Sri Lanka & & $\mathbf{1 . 0 0 0}$ & 0.697 & 0.470 & 0.376 & 0.521 & 0.123 \\
Indonesia & & & $\mathbf{1 . 0 0 0}$ & 0.863 & 0.802 & 0.903 & 0.202 \\
Korea & & & $\mathbf{1 . 0 0 0}$ & 0.847 & 0.727 & 0.072 \\
Malaysia & & & & $\mathbf{1 . 0 0 0}$ & 0.799 & 0.021 \\
Philippines & & & & & $\mathbf{1 . 0 0 0}$ & 0.399 \\
Thailand & & & & & & $\mathbf{1 . 0 0 0}$ \\
\hline
\end{tabular}

Adjustment coefficient
A
$0.0044^{* *}(0.0017)$
B
$0.9740 *(0.0118)$

Note: ${ }^{*}=$ rejection of null hypothesis at 1 percent, ${ }^{* *}$ at 5 percent, ${ }^{* * *}$ at 10 percent. Values in bold are different from 0 with a significance level alpha $=0.05$. Values in parentheses are standard errors.

Source: Author's calculations.

Table 8: DCC $(1,1)$ model results

\begin{tabular}{lrrrrr}
\hline & Average & $\begin{array}{c}\text { Standard } \\
\text { deviation }\end{array}$ & $\begin{array}{c}\text { Trend } \\
\left({ }^{*} \mathbf{1 0 0 0}\right)\end{array}$ & t-statistic & $\Delta \mathbf{p}$ \\
\hline Panel A: US-EFA DCC & & & & \\
Pakistan & -0.03057 & 0.00252 & -0.038 & -17.3610 & $-1.14 \%$ \\
Bangladesh & 0.01672 & 0.15625 & 0.066 & -0.2950 & $-7.79 \%$ \\
China & -0.12658 & 0.08963 & -0.127 & -0.9882 & $13.40 \%$ \\
India & -0.03934 & 0.16051 & -0.214 & -0.9279 & $2.69 \%$ \\
Sri Lanka & -0.04201 & 0.01644 & -0.230 & -14.0260 & $-2.03 \%$ \\
Indonesia & -0.04830 & 0.07473 & -0.040 & 0.3691 & $2.71 \%$ \\
Korea & -0.06074 & 0.04147 & -0.246 & 4.3283 & $6.41 \%$ \\
Malaysia & 0.03466 & 0.11838 & -0.055 & -0.3200 & $9.77 \%$ \\
Philippines & 0.19403 & 0.24046 & -3.027 & -11.5910 & $-45.13 \%$ \\
Thailand & 0.98292 & 0.01626 & 0.238 & 15.7720 & $3.12 \%$ \\
\hline Panel B: EUR-EFA DCC & & & & \\
Pakistan & -0.07546 & 0.07583 & -0.330 & -3.1091 & $-3.68 \%$ \\
Bangladesh & -0.01039 & 0.02987 & 0.192 & 4.7557 & $-0.87 \%$ \\
China & -0.08531 & 0.13009 & -0.570 & -3.1295 & $-7.69 \%$ \\
India & 0.13019 & 0.25236 & 0.114 & 0.3154 & $12.40 \%$ \\
Sri Lanka & -0.04699 & 0.00991 & -0.175 & -31.0330 & $-2.65 \%$ \\
\hline
\end{tabular}




\begin{tabular}{lrcccc}
\hline & Average & $\begin{array}{c}\text { Standard } \\
\text { deviation }\end{array}$ & $\begin{array}{c}\text { Trend } \\
\left({ }^{*} \mathbf{1 0 0 0}\right)\end{array}$ & t-statistic & $\Delta \mathbf{p}$ \\
\hline Indonesia & -0.05301 & 0.20087 & -0.026 & -0.0887 & $2.44 \%$ \\
Korea & -0.01373 & 0.13023 & 1.975 & 17.1980 & $2.67 \%$ \\
Malaysia & -0.00295 & 0.04502 & -0.044 & -0.6765 & $1.63 \%$ \\
Philippines & -0.06830 & 0.06703 & -0.007 & -0.0671 & $-2.72 \%$ \\
Thailand & 0.99591 & 0.00577 & 0.001 & 0.1113 & $2.05 \%$ \\
\hline Panel C: JAP-EFA DCC & & & & \\
Pakistan & -0.10668 & 0.01612 & -0.081 & -3.6321 & $-3.59 \%$ \\
Sri Lanka & 0.01448 & 0.04798 & 0.012 & -0.1742 & $-5.24 \%$ \\
Bangladesh & 0.06727 & 0.12351 & 0.439 & 2.5140 & $1.03 \%$ \\
China & -0.04032 & 0.08019 & -0.376 & -3.3605 & $-3.94 \%$ \\
India & -0.06090 & 0.07897 & 0.514 & 4.8148 & $8.24 \%$ \\
Indonesia & -0.00880 & 0.05145 & -0.113 & 1.5435 & $-2.99 \%$ \\
Korea & -0.80686 & 0.35681 & 0.208 & -30.0350 & $-1.19 \%$ \\
Malaysia & 0.02592 & 0.14655 & -0.103 & -0.4893 & $-16.60 \%$ \\
Philippines & 0.01351 & 0.07798 & -0.289 & -2.6269 & $-4.26 \%$ \\
Thailand & -0.14459 & 0.08645 & -0.950 & -9.3152 & $-15.10 \%$ \\
\hline
\end{tabular}

Note: The slope of the regression of conditional correlation $\varrho_{i j, t}$ is represented by "trend" on a constant. The t-ratio represents the t-statistic. 4 denotes the difference between the last and first fitted values of the conditional correlation regression on the time trend of a zero mean and constant.

Source: Author's calculations.

\subsection{Conditional Correlation Coefficient Analysis}

Next, we study the impact of a crisis on dynamic correlation for further insights into the additional independent variables that explain stock market correlation. Initially, we had considered the impact of external shocks on the coefficients of conditional correlation. The financial turmoil factor is very important in explaining the conditional correlation coefficient in this case: stock market turbulence has implications for international investors and the diversification of stocks.

We use dummy variables for three different, evenly spaced crisis periods to analyze their impact on dynamic correlation in the sample markets. The regression analysis takes the time-varying correlation coefficient as a dependent variable and each of the crisis dummy variables as explanatory variables. The first dummy variable represents the dot.com bubble from 10 March 2000 to 27 September 2002. The second dummy is the 2008/09 stock market crash from 26 September 2008 to 31 December 2009. 
The third dummy variable is the European debt crises from 1 January 2011 to 30 November 2013. Each dummy variable is equal to 1 for a crisis period and 0 otherwise. The resulting equation is expressed below:

$\rho_{i j, t}=\omega+\sum_{k=1}^{3} \alpha_{k} D M_{k, t}+\epsilon_{i j, t}$

The first column of Table 9 underlines the effect of the dot.com bubble crisis on dynamic correlation between EFA markets and the US. Since the crisis was related to information technology, it had a negative impact on returns in Thailand though the impact on returns in Pakistan was positive (perhaps reflecting Pakistan's role as a hedge market). In terms of the European and EFA market correlations during the dot.com crisis, there was a negative impact in China and Indonesia. However, in the case of correlation between Japan and the EFA markets, only Bangladesh and India are affected.

Table 9: DCC $(1,1)$ model applied to crisis periods

\begin{tabular}{lccc}
\hline & $\begin{array}{c}\text { Dot.com bubble } \\
\text { (10 Mar 2000-27 } \\
\text { Sep 2002) }\end{array}$ & $\begin{array}{c}\text { 2008 stock market } \\
\text { crash (26 Sep } \\
\text { 2008-31 Dec 2009) }\end{array}$ & $\begin{array}{c}\text { European debt } \\
\text { crisis (1 Jan 2011- } \\
\text { 30 Nov 2013) }\end{array}$ \\
\hline Panel A: US-EFA DCC & & & \\
Pakistan & $0.004436^{*}$ & 0.000139 & $-0.000758^{*}$ \\
Bangladesh & $(0.000373)$ & $(0.000488)$ & $(0.000356)$ \\
China & 0.029214 & 0.019541 & -0.013485 \\
& $(0.032338)$ & $(0.042315)$ & $(0.030902)$ \\
India & -0.001154 & -0.009799 & $-0.053948^{*}$ \\
Sri Lanka & $(0.018104)$ & $(0.023690)$ & $(0.017301)$ \\
Indonesia & -0.007859 & $0.066895^{*}$ & $0.079637^{*}$ \\
Korea & $(0.011671)$ & $(0.015272)$ & $(0.011153)$ \\
& $0.030469^{*}$ & 0.002118 & $-0.008326^{*}$ \\
Malaysia & $(0.002183)$ & $(0.002856)$ & $(0.002086)$ \\
& 0.003615 & 0.010710 & 0.002893 \\
Philippines & $(0.015517)$ & $(0.020304)$ & $(0.014828)$ \\
Thailand & -0.009701 & 0.005353 & 0.009987 \\
& $(0.008522)$ & $(0.011151)$ & $(0.008144)$ \\
& 0.006360 & 0.041414 & -0.004256 \\
& $(0.024470)$ & $(0.032020)$ & $(0.023384)$ \\
& $0.313054^{*}$ & 0.019881 & -0.017585 \\
& $(0.043342)$ & $(0.056713)$ & $(0.041417)$ \\
& $-0.028889^{*}$ & -0.003058 & $0.010023^{*}$ \\
& $(0.002183)$ & $(0.002856)$ & $(0.002086)$ \\
\hline
\end{tabular}




\begin{tabular}{|c|c|c|c|}
\hline & $\begin{array}{l}\text { Dot.com bubble } \\
\text { (10 Mar 2000-27 } \\
\text { Sep 2002) } \\
\end{array}$ & $\begin{array}{c}2008 \text { stock market } \\
\text { crash (26 Sep } \\
2008-31 \text { Dec 2009) }\end{array}$ & $\begin{array}{c}\text { European debt } \\
\text { crisis (1 Jan 2011- } \\
30 \text { Nov 2013) } \\
\end{array}$ \\
\hline \multicolumn{4}{|c|}{ Panel B: EUR-EFA DCC } \\
\hline Pakistan & $\begin{array}{c}0.015554 \\
(0.015453)\end{array}$ & $\begin{array}{l}-0.005393 \\
(0.020221)\end{array}$ & $\begin{array}{l}-0.031311^{*} \\
(0.014767)\end{array}$ \\
\hline Bangladesh & $\begin{array}{l}0.152492^{*} \\
(0.033448)\end{array}$ & $\begin{array}{l}-0.055715 \\
(0.043767)\end{array}$ & $\begin{array}{l}0.148375^{*} \\
(0.031963)\end{array}$ \\
\hline China & $\begin{array}{c}0.018173 \\
(0.044026)\end{array}$ & $\begin{array}{l}-0.122874^{*} \\
(0.057608)\end{array}$ & $\begin{array}{l}0.127697^{*} \\
(0.042071)\end{array}$ \\
\hline India & $\begin{array}{l}-0.019599^{*} \\
(0.010662)\end{array}$ & $\begin{array}{l}0.057095^{*} \\
(0.013951)\end{array}$ & $\begin{array}{c}0.005239 \\
(0.010188)\end{array}$ \\
\hline Sri Lanka & $\begin{array}{l}0.018133^{*} \\
(0.001082)\end{array}$ & $\begin{array}{l}0.003919 * \\
(0.001416)\end{array}$ & $\begin{array}{l}-0.009003^{*} \\
(0.001034)\end{array}$ \\
\hline Indonesia & $\begin{array}{c}0.024201 \\
(0.041677)\end{array}$ & $\begin{array}{l}-0.013050 \\
(0.054535)\end{array}$ & $\begin{array}{c}0.015861 \\
(0.398242)\end{array}$ \\
\hline Korea & $\begin{array}{c}-0.086352^{*} \\
(0.021460)\end{array}$ & $\begin{array}{l}-0.062261^{*} \\
(0.028081)\end{array}$ & $\begin{array}{l}0.155977^{*} \\
(0.020507)\end{array}$ \\
\hline Malaysia & $\begin{array}{l}0.023033^{*} \\
(0.009122)\end{array}$ & $\begin{array}{l}0.024943^{*} \\
(0.011936)\end{array}$ & $\begin{array}{c}0.009746 \\
(0.008717)\end{array}$ \\
\hline Philippines & $\begin{array}{c}0.006315 \\
(0.013906)\end{array}$ & $\begin{array}{c}0.012916 \\
(0.018196)\end{array}$ & $\begin{array}{c}0.004243 \\
(0.013288)\end{array}$ \\
\hline Thailand & $\begin{array}{c}0.127478^{*} \\
(0.015909)\end{array}$ & $\begin{array}{l}0.147003^{*} \\
(0.020817) \\
\end{array}$ & $\begin{array}{l}-0.039518^{*} \\
(0.015202)\end{array}$ \\
\hline \multicolumn{4}{|c|}{ Panel C: JAP-EFA DCC } \\
\hline Pakistan & $\begin{array}{c}0.015139 * \\
(0.003039)\end{array}$ & $\begin{array}{l}-0.007817^{*} \\
(0.003917)\end{array}$ & $\begin{array}{l}-0.003494 \\
(0.002905)\end{array}$ \\
\hline Bangladesh & $\begin{array}{l}-0.147646^{*} \\
(0.031552)\end{array}$ & $\begin{array}{l}-0.361641^{*} \\
(0.041287)\end{array}$ & $\begin{array}{l}-0.072444^{*} \\
(0.030151)\end{array}$ \\
\hline China & $\begin{array}{c}-0.007592 \\
0.017362\end{array}$ & $\begin{array}{l}0.058159^{*} \\
(0.022719)\end{array}$ & $\begin{array}{c}0.007992 \\
(0.016592)\end{array}$ \\
\hline India & $\begin{array}{c}-0.027760^{* *} \\
(0.015856)\end{array}$ & $\begin{array}{l}0.086697^{*} \\
(0.020747)\end{array}$ & $\begin{array}{l}-0.011970 \\
(0.015152)\end{array}$ \\
\hline Sri Lanka & $\begin{array}{c}0.013256 \\
(0.008828)\end{array}$ & $\begin{array}{l}0.080369^{*} \\
(0.011552)\end{array}$ & $\begin{array}{c}0.013095 \\
(0.008436)\end{array}$ \\
\hline Indonesia & $\begin{array}{l}0.017311^{*} \\
(0.008051)\end{array}$ & $\begin{array}{l}0.121747^{*} \\
(0.010535)\end{array}$ & $\begin{array}{l}0.024088^{*} \\
(0.007694)\end{array}$ \\
\hline Korea & $\begin{array}{c}0.634551^{*} \\
(0.045458)\end{array}$ & $\begin{array}{l}-0.237901^{*} \\
(0.059482)\end{array}$ & $\begin{array}{l}-0.192584^{*} \\
(0.043409)\end{array}$ \\
\hline Malaysia & $\begin{array}{c}0.006965 \\
(0.027251)\end{array}$ & $\begin{array}{l}0.224016^{*} \\
(0.035658)\end{array}$ & $\begin{array}{c}-0.020481 \\
(0.026041)\end{array}$ \\
\hline
\end{tabular}




\begin{tabular}{lccc}
\hline & $\begin{array}{c}\text { Dot.com bubble } \\
\text { (10 Mar 2000-27 } \\
\text { Sep 2002) }\end{array}$ & $\begin{array}{c}\text { 2008 stock market } \\
\text { crash (26 Sep } \\
\text { 2008-31 Dec 2009) }\end{array}$ & $\begin{array}{c}\text { European debt } \\
\text { crisis (1 Jan 2011- } \\
\text { 30 Nov 2013) }\end{array}$ \\
\hline Philippines & $0.050120^{*}$ & $0.173213^{*}$ & -0.001703 \\
Thailand & $(0.012344)$ & $(0.016153)$ & $(0.011796)$ \\
& $0.167942^{*}$ & 0.028497 & $-0.041682^{*}$ \\
& $(0.021216)$ & $(0.027761)$ & $(0.020274)$ \\
\hline
\end{tabular}

Source: Author's calculations.

The second column of Table 9 corresponds to the 2008 stock market crash (the dummy variable is DM2). In terms of correlation with the US, India was the only market in which returns are affected. With respect to European markets, China and Korea exhibit reduced returns. This shows that all these markets were subject to dynamic correlation.

In terms of dynamic conditional correlation between the Japanese and EFA markets, only Pakistan, Bangladesh and Korea show negative values, indicating the effect of the global financial crisis on these markets. A key finding is that the coefficient values increase during the 2008 financial crisis and then decrease (at a falling rate) during the European debt crisis. Most markets also exhibit herding behavior, which can be attributed to the financial liberalization in emerging markets. Since this helped international investors diversify their portfolios in these markets to minimize risk, we can argue that the increasing level of foreign ownership in EFA markets has given rise to herding behavior.

Finally the third column of Table 9 shows the impact of the European debt crisis. In terms of correlations the US, returns in Pakistan. China, India and Sri Lanka were negatively affected. In terms of correlation with the European markets, returns in Pakistan and Thailand were negatively affected. And in terms of correlations with Japanese and EFA markets returns in Bangladesh and Korea were negatively affected.

In light of these results, most EFA markets appear to have experienced a disturbance during the sample crisis periods. This has key implications for investors regarding international diversification. Our findings support most crisis-contingent theories of asset market linkages in East Asia. 


\section{Concluding Remarks}

This paper applies a multivariate DCC framework to determine the short-term relationship between EFA markets (Pakistan, Bangladesh, China, India, Sri Lanka, Indonesia, Korea, Malaysia, the Philippines and Thailand) and developed markets (the US, Europe and Japan), based on a monthly return series for January 2000 to December 2014. The coefficients of conditional correlation show significant variation over the sample period in general and during three specific crisis periods (the dot.com bubble, the 2008 stock market crash and the European debt crisis). The findings support the use of the multivariate GARCH-DCC framework to identify increased correlation coefficients in times of financial turmoil. These results are in accordance with Li (2007), Yu et al. (2010), Aloui et al. (2011), Samarakoon (2011), Kenourgios and Padhi (2012) and Chua et al. (2012).

The analysis of conditional correlation favors the contagion effect due to herding behavior in EFA financial markets. However, the financial contagion hypothesis cannot be accepted across the panel for all crisis periods. The increased impact on EFA markets can also be attributed to greater sensitivity to incoming foreign investment. The results indicate that all crisis periods do not have a uniform impact on EFA markets. Rather, each market behaves differently in each crisis period. Nonetheless, the global financial crisis of 2008 had a significant impact on these markets in the form of financial contagion followed by herding behavior.

Other factors also play an important role as control variables during periods of financial turbulence, of which exchange rates and international oil prices are the most influential (Rehman, 2014). While this study focused on measuring the impact of spillovers from developed equity markets on EFA financial markets, other market and financial variables are not taken into account (see Rehman \& Shah, 2016a, 2016b). Therefore, the study could be extended by incorporating these variables along with the control variables (exchange rates and international oil prices) before, during and after a global crisis. 


\section{References}

Aloui, R., Aïssa, M. S. B., \& Nguyen, D. K. (2011). Global financial crisis, extreme interdependences and contagion effects: The role of economic structure? Journal of Banking and Finance, 35(1), 130-141.

Bae, K.-H., \& Karolyi, G. (1994). Good news, bad news and international spillovers of stock return volatility between Japan and the US. Pacific-Basin Finance Journal, 2(4), 405-438.

Bayoumi, T., Fazio, G., Kumar, M., \& MacDonald, R. (2007). Fatal attraction: Using distance to measure contagion in good times as well as bad. Review of Financial Economics, 16(3), 259-273.

Bekaert, G., Harvey, C. R., \& Lundblad, C. (2005). Does financial liberalization spur growth? Journal of Financial Economics, 77(1), 3-55.

Bensafta, K. M., \& Semedo, G. (2014). Market volatility transmission and central banking: What happened during the subprime crisis? International Economic Journal, 28(4), 559-588.

Bollerslev, T., Chou, R., \& Kroner, K. F. (1992). ARCH modeling in finance: A review of the theory and empirical evidence. Journal of Econometrics, 52(1-2), 5-59.

Boyer, B. H., Kumagai, T., \& Yuan, K. (2006). How do crises spread? Evidence from accessible and inaccessible stock indices. Journal of Finance, 61(2), 957-1003.

Broner, F. A., Gelos, R. G., \& Reinhart, C. M. (2006). When in peril, retrench: Testing the portfolio channel of contagion. Journal of International Economics, 69(1), 203-230.

Caporale, G. M., Cipollini, A., \& Spagnolo, N. (2005). Testing for contagion: A conditional correlation analysis. Journal of Empirical Finance, 12(3), 476-489.

Caporale, G. M., Pittis, N., \& Spagnolo, N. (2006). Volatility transmission and financial crises. Journal of Economics and Finance, 30(3), 376-390.

Carrieri, F., Errunza, V., \& Hogan, K. (2007). Characterizing world market integration through time. Journal of Financial and Quantitative Analysis, 42(4), 915-940. 
Cartapanis, A., \& Gilles, P. (2003). Prévention et gestion des crises financières internationales: Une analyse rétrospective de $\mathrm{H}$. Thornton. Papers in Political Economy, 2, 175-210.

Chiang, T. C., Jeon, B. N., \& Li, H. (2007). Dynamic correlation analysis of financial contagion: Evidence from Asian markets. Journal of International Money and Finance, 26(7), 1206-1228.

Choe, K., Choi, P., Nam, K., \& Vahid, F. (2012). Testing financial contagion on heteroskedastic asset returns in time-varying conditional correlation. Pacific-Basin Finance Journal, 20(2), 271-291.

Chua, C. L., Suardi, S., \& Tsiaplias, S. (2012). An impulse-response function for a VAR with multivariate GARCH-in-mean that incorporates direct and indirect transmission of shocks. Economics Letters, 117(2), 452-454.

Claessens, S., Dornbush, R., \& Park, Y. C. (2001). Contagion: Why crises spread and how this can be stopped. In S. Claessens \& K. J. Forbes (Eds.), International financial contagion. New York: Springer.

Cole, H. L., \& Kehoe, T. J. (1996). A self-fulfilling model of Mexico's 19941995 debt crisis. Journal of International Economics, 41(3-4), 309-330.

Collins, D., \& Gavron, S. (2004). Channels of financial market contagion. Applied Economics, 36(21), 2461-2469.

Corsetti, G., Pericoli, M., \& Sbracia, M. (2005). 'Some contagion, some interdependence': More pitfalls in tests of financial contagion. Journal of International Money and Finance, 24(8), 1177-1199.

Dooley, M., \& Hutchison, M. (2009). Transmission of the US subprime crisis to emerging markets: Evidence on the decoupling-recoupling hypothesis. Journal of International Money and Finance, 28(8), 1331-1349.

Dungey, M., Fry, R., González-Hermosillo, B., \& Martin, V. (2002). The transmission of contagion in developed and developing international bond markets. In Risk measurement and systemic risk: Proceedings of the Third Joint Central Bank Research Conference (pp. 6174). Basel: Bank for International Settlements. 
Dungey, M., Fry, R., González-Hermosillo, B., \& Martin, V. (2004). Empirical modeling of contagion: A review of methodologies (Working Paper No. 78). Washington, DC: International Monetary Fund.

Edwards, S. (1998). Interest rate volatility, capital controls and contagion (Working Paper No. 6756). Cambridge, MA: National Bureau of Economic Research.

Edwards, S., \& Susmel, R. (2003). Interest rate volatility in emerging markets. Review of Economics and Statistics, 85(2), 328-348.

Eichengreen, B., \& Hausmann, R. (1999). Exchange rates and financial fragility (Working Paper No. 7418). Cambridge, MA: National Bureau of Economic Research.

Engle, R. (2002). Dynamic conditional correlation: A simple class of multivariate generalized autoregressive conditional heteroskedasticity models. Journal of Business and Economic Statistics, 20(3), 339-350.

Engle, R. F., \& Kroner, K. F. (1995). Multivariate simultaneous generalized ARCH. Econometric Theory, 11(1), 122-150.

Flood, R. P., \& Garber, P. M. (1984). Collapsing exchange-rate regimes: Some linear examples. Journal of International Economics, 17(1-2), 1-13.

Fong, W. M. (2003). Correlation jumps. Journal of Applied Finance, 13(1), 29-45.

Forbes, K., \& Rigobon, R. (2001). Measuring contagion: Conceptual and empirical issues. In S. Claessens \& K. J. Forbes (Eds.), International financial contagion (pp. 43-66). New York: Springer.

Forbes, K. J., \& Rigobon, R. (2002). No contagion, only interdependence: Measuring stock market co-movements. Journal of Finance, 57(5), 2223-2261.

Fratzscher, M. (2002). Financial market integration in Europe: On the effects of EMU on stock markets. International Journal of Finance and Economics, 7(3), 165-193. 
Ham, H., Kim, T. J., \& Boyce, D. (2005). Assessment of economic impacts from unexpected events with an interregional commodity flow and multimodal transportation network model. Transportation Research Part A: Policy and Practice, 39(10), 849-860.

Hamao, Y., Masulis, R., \& Ng, V. (1990). Correlations in price changes and volatility across international stock markets. Review of Financial Studies, 3(2), 281-307.

Hirshleifer, D., \& Teoh, S. H. (2003). Herd behavior and cascading in capital markets: A review and synthesis. European Financial Management, 9(1), 25-66.

Jeon, J. Q., \& Moffett, C. M. (2010). Herding by foreign investors and emerging market equity returns: Evidence from Korea. International Review of Economics and Finance, 19(4), 698-710.

Kaminsky, G. L., \& Reinhart, C. M. (2000). On crises, contagion and confusion. Journal of International Economics, 51(1), 145-168.

Kaminsky, G. L., Reinhart, C. M., \& Vegh, C. A. (2003). The unholy trinity of financial contagion. Journal of Economic Perspectives, 17(4), 51-74.

Karolyi, G. A. (2003). Does international financial contagion really exist? International Finance, 6(2), 179-199.

Kenourgios, D., \& Padhi, P. (2012). Emerging markets and financial crises: Regional, global or isolated shocks? Journal of Multinational Financial Management, 22(1-2), 24-38.

Kenourgios, D., Samitas, A., \& Paltalidis, N. (2011). Financial crises and stock market contagion in a multivariate time-varying asymmetric framework. Journal of International Financial Markets, Institutions and Money, 21(1), 92-106.

King, M. A., \& Wadhwani, S. (1990). Transmission of volatility between stock markets. Review of Financial Studies, 3(1), 5-33.

Kodres L. E., \& Pritsker, M. (2002). A rational expectations model of financial contagion. Journal of Finance, 57(2), 769-799.

Krugman, P. (1997). The age of diminished expectations: US economic policy in the 1990s. Cambridge, MA: MIT Press. 
Krugman, P. (2001). Analytical afterthoughts on the Asian crisis. In T. Negishi, R. V. Ramachandran \& K. Mino (Eds.), Economic theory, dynamics and markets (pp. 243-255). New York: Springer.

Kyle, A., \& Xiong, W. (2001). Contagion as a wealth effect. Journal of Finance, 56(4), 1401-1440.

Li, H. (2007). International linkages of the Chinese stock exchanges: A multivariate GARCH analysis. Applied Financial Economics, 17(4), 285-297.

Longin, F., \& Solnik, B. (1995). Is the correlation in international equity returns constant: 1960-1990? Journal of International Money and Finance, 14(1), 3-26.

Martinez, C., \& Ramirez, M. (2011). International propagation of shocks: An evaluation of contagion effects for some Latin American countries. Macroeconomics and Finance in Emerging Market Economies, $4(2), 213-233$.

Masson, P. (1998). Contagion; monsoonal effects, spillovers and jumps between multiple equilibria (Working Paper No. 142). Washington, DC: International Monetary Fund.

Masson, P. (1999). Contagion: Macroeconomic models with multiple equilibria. Journal of International Money and Finance, 18, 587-602.

$\mathrm{Ng}$, A. (2000). Volatility spillover effects from Japan and the US to the PacificBasin. Journal of International Money and Finance, 19(2), 207-233.

Obstfeld, M., \& Rogoff, K. (1994). Exchange rate dynamics redux (Working Paper No. 4693). Cambridge, MA: National Bureau of Economic Research.

Pericoli, M., \& Sbracia, M. (2003). A primer on financial contagion. Journal of Economic Surveys, 17(4), 571-608.

Pritsker, M. (2001). The channels for financial contagion. In S. Claessens \& K. J. Forbes (Eds.), International financial contagion. New York: Springer.

Rehman, M. (2014). Relationship between stock market volatility and exchange rate volatility. Pakistan Business Review, 16(1), 34-49. 
Rehman, M., \& Shah, S. M. A. (2016a). Determinants of return's comovement for effective portfolio diversification among regional stock markets. Revista Evidenciação Contábil E Finanças, 4(1), 84-96.

Rehman, M., \& Shah, S. M. A. (2016b). Does bilateral market and financial integration explain international co-movement patterns? International Journal of Financial Studies, 4(2), 1-13.

Sachs, J., Tornell, A., \& Velasco, A. (1996). Financial crises in emerging markets: The lessons from 1995. Brookings Papers on Economic Activity, 27, 147-216.

Samarakoon, L. P. (2011). Stock market interdependence, contagion and the US financial crisis: The case of emerging and frontier markets. Journal of International Financial Markets, Institutions and Money, 21(5), 724-742.

Serwa, D., \& Bohl, M. T. (2005). Financial contagion vulnerability and resistance: A comparison of European stock markets. Economic Systems, 29, 344-362.

Suardi, S. (2012). When the US sneezes, the world catches cold: Are worldwide stock markets stable? Applied Financial Economics, 22(23), 1961-1978.

Syllignakis, M. N., \& Kouretas, G. P. (2011). Dynamic correlation analysis of financial contagion: Evidence from the Central and Eastern European markets. International Review of Economics and Finance, 20(4), 717-732.

Wongswan, J. (2006). Transmission of information across international equity markets. Review of Financial Studies, 19(4), 1157-1189.

Yu, I.-W., Fung, K.-P., \& Tam, C.-S. (2010). Assessing financial market integration in Asia-equity markets. Journal of Banking and Finance, 34(12), 2874-2885. 